\title{
Sulfur-tolerant $\mathrm{Pt} / \mathrm{CeO}_{2}$ catalyst with enhanced
}

\author{
oxygen storage capacity by controlling the $\mathrm{Pt}$
}

\section{content for the waste-to-hydrogen processes}

Yeol-Lim Lee ${ }^{\text {a }}$, Kyoung-Jin Kimª, Ga-Ram Honga, Seon-Yong Ahn, Beom-Jun Kimª, Ho-

Ryong Park ${ }^{\mathrm{a}}$, Seong-Jin Yun ${ }^{\mathrm{a}}$, Jong Wook Bae ${ }^{\mathrm{b}}$, Byong-Hun Jeon ${ }^{\mathrm{c}}$, and Hyun-Seog Roh ${ }^{\mathrm{a}, *}$

a Department of Environmental Engineering, Yonsei University, 1 Yonseidae-gil, Wonju,

Gangwon 26493, Republic of Korea

b School of Chemical Engineering, Sungkyunkwan University (SKKU), 2066 Seobu-ro,

Jangan-gu, Suwon, Gyeonggi-do, 16419, Republic of Korea

${ }^{\mathrm{c}}$ Department of Natural Resources and Environmental Engineering, Hanyang University, 222

Wangsimni-ro, Seongdong-gu, Seoul 04763, Republic of Korea

Corresponding Authors 
E-mail: hsroh@yonsei.ac.kr (Hyun-Seog Roh, +82-33-760-2834) 
Number of pages: 8

Number of figures: 4

Number of tables: 2

\section{Table of Contents of Supporting Information}

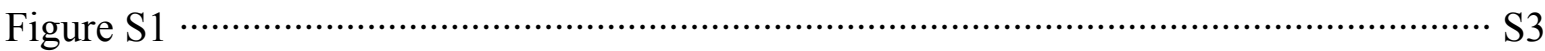

Figure S2

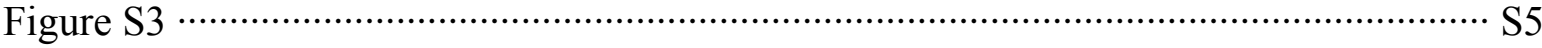

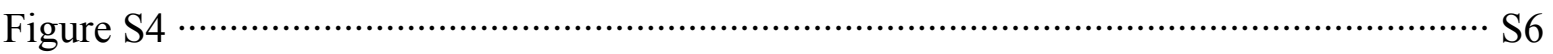

Table S1

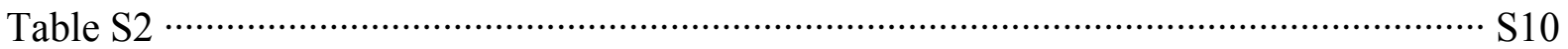


(A)

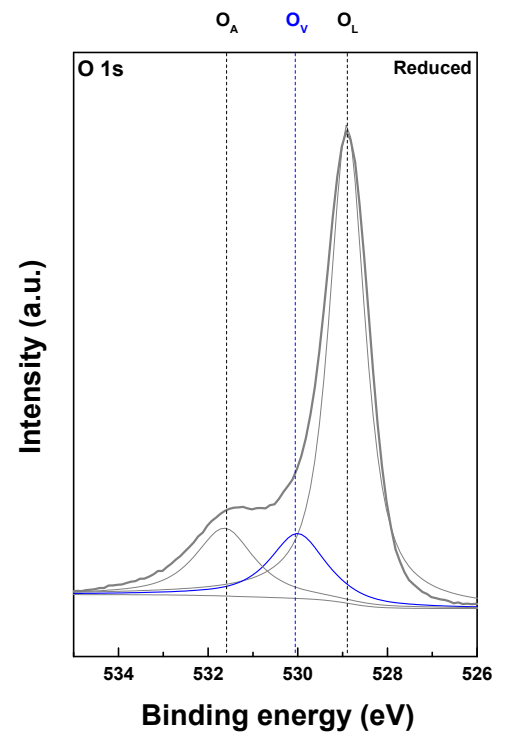

(B)

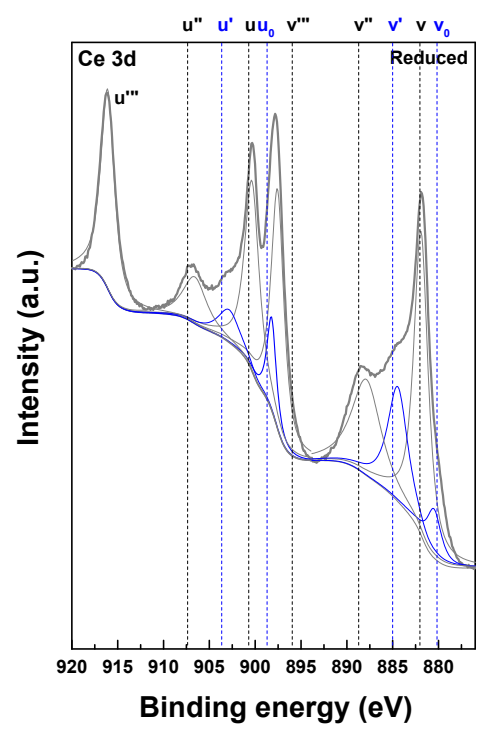

Figure S1. XPS spectra of reduced $\mathrm{CeO}_{2}$ support: (A) $\mathrm{O}$ 1s and (B) $\mathrm{Ce} 3 \mathrm{~d}$ 


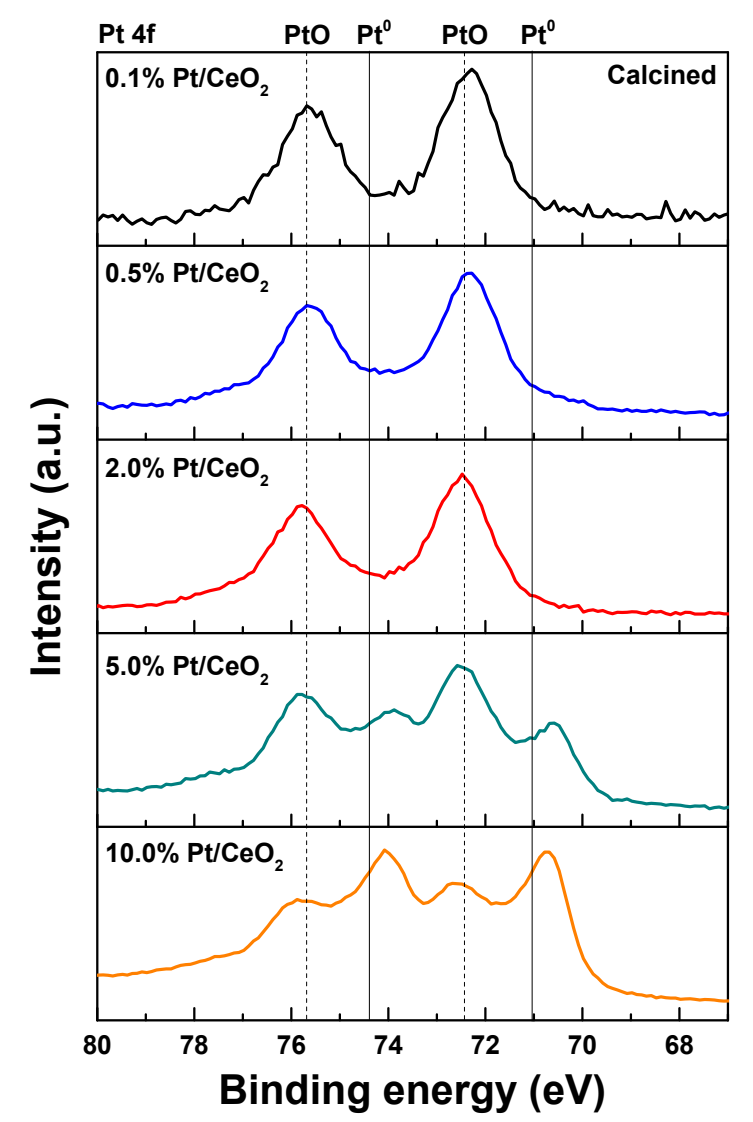

Figure S2. XPS Pt $4 \mathrm{f}$ spectra of calcined $\mathrm{Pt} / \mathrm{CeO}_{2}$ catalysts.

In the case of $5.0 \%$ and $10.0 \% \mathrm{Pt} / \mathrm{CeO}_{2}$ catalyst, the $\mathrm{PtO}_{x}$ in the catalyst has partially reduced to the $\mathrm{Pt}^{0}$ during the calcination. This is due to the decomposition of $\mathrm{PtO}_{x}$ species which are weakly interacting with the support [Liotta et al., Applied Catalysis B: Environmental 48 (2004) 133-149]. 

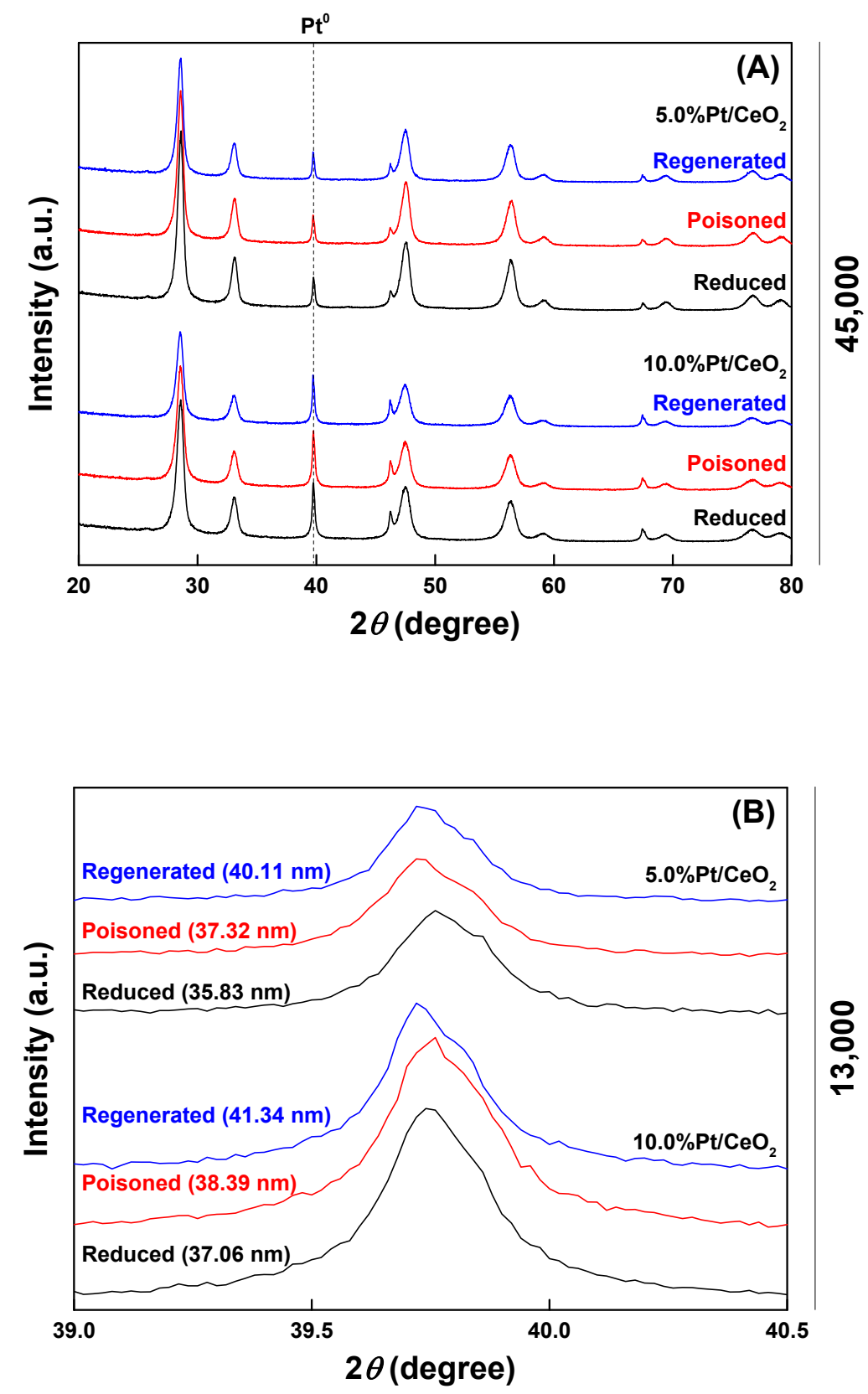

Figure S3. XRD patterns of reduced, poisoned, and regenerated $\mathrm{Pt} / \mathrm{CeO}_{2}$ catalysts ( $\mathrm{Pt}$ loading $=5.0$ and $10.0 \mathrm{wt} \%$ ). 

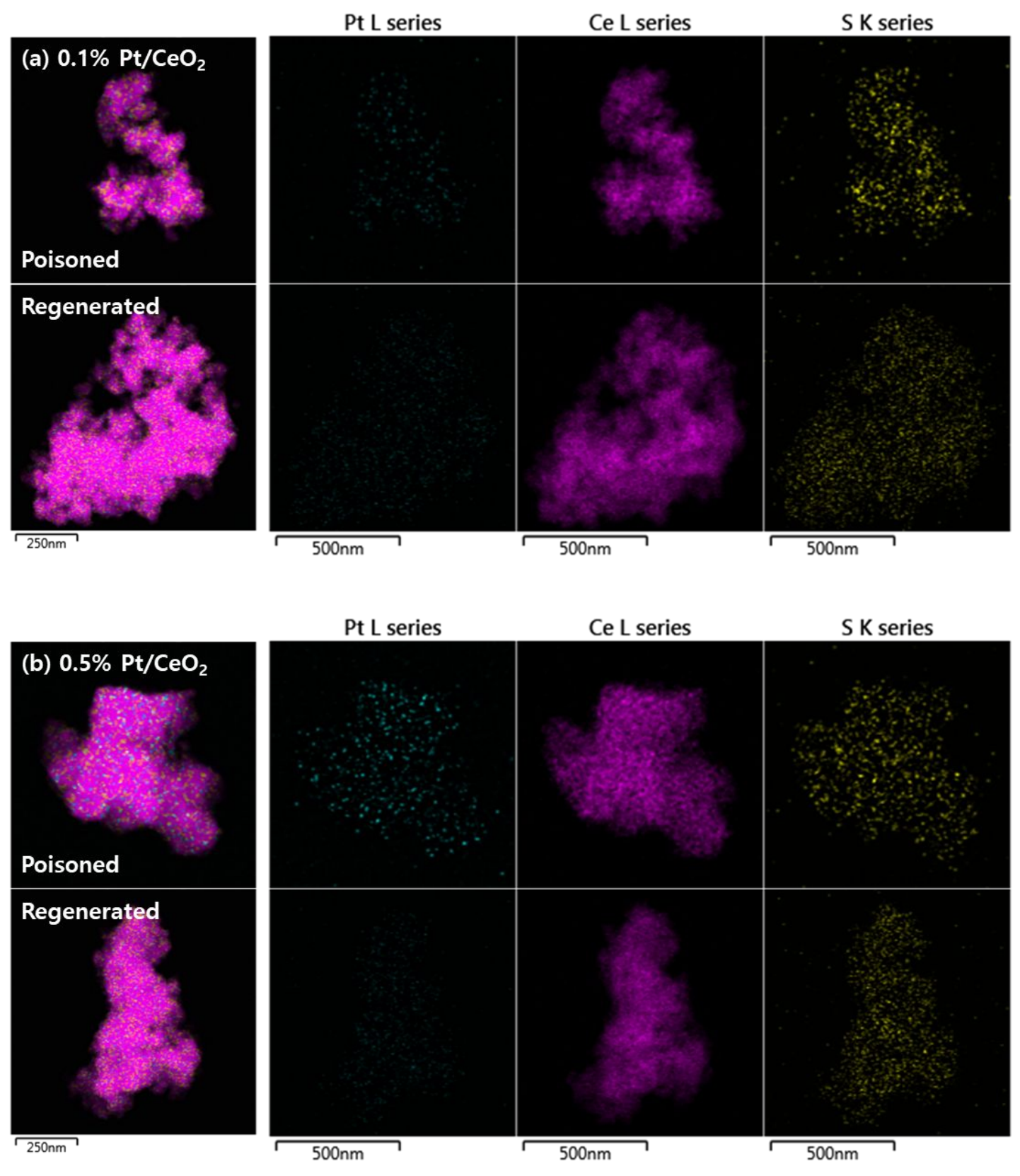

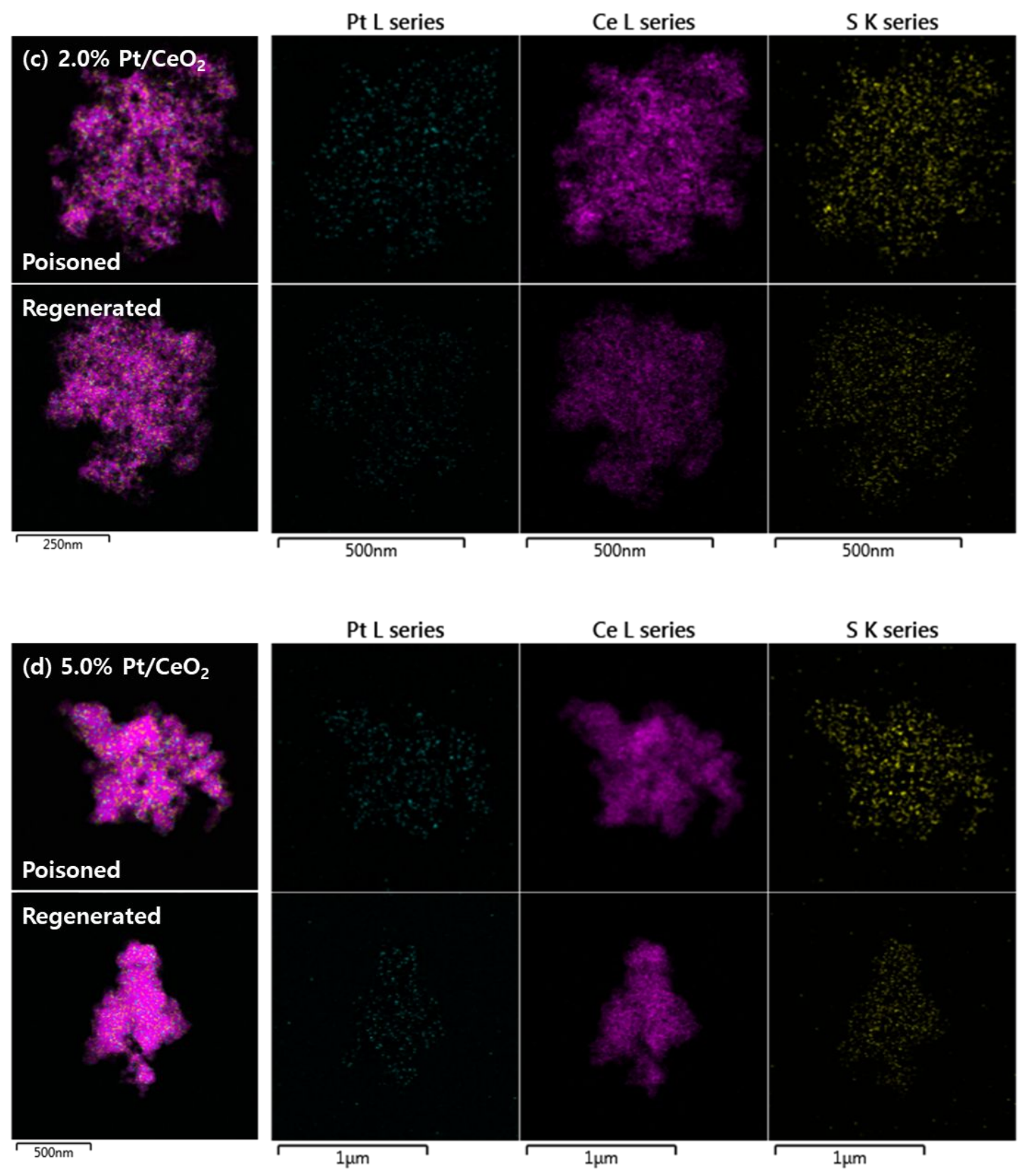


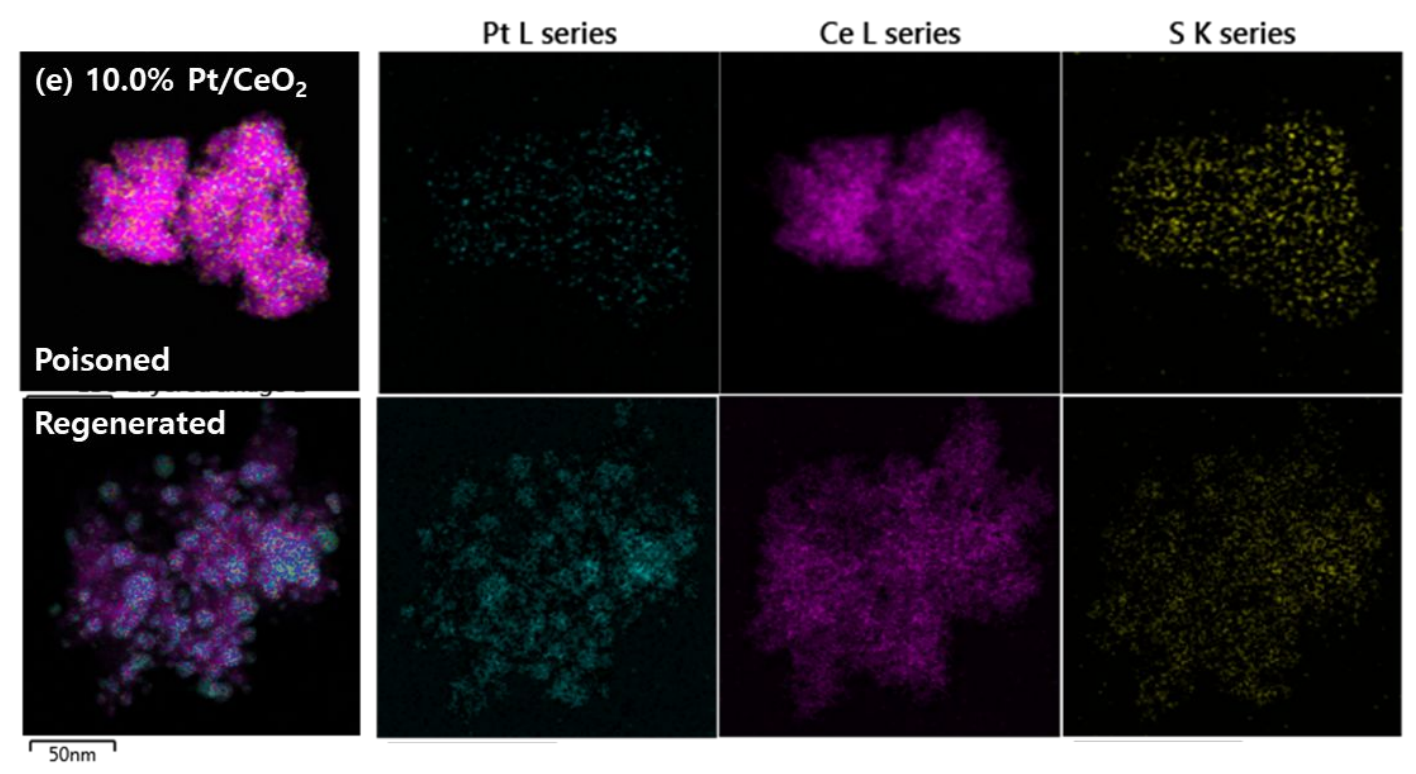

Figure S4. TEM and EDX mapping images of poisoned and regenerated $\mathrm{Pt} / \mathrm{CeO}_{2}$ catalysts with various Pt loadings. 
Table S1. Crystallite size and unit cell parameter of $\mathrm{CeO}_{2}$ in $\mathrm{Pt} / \mathrm{CeO}_{2}$ catalysts with various $\mathrm{Pt}$ loadings.

\begin{tabular}{ccc}
\hline $\begin{array}{c}\mathrm{Pt} \\
\text { loading }\end{array}$ & $\begin{array}{c}\text { Crystallite } \\
\text { size of } \mathrm{CeO}_{2} \\
(\mathrm{~nm})^{\mathrm{a}}\end{array}$ & $\begin{array}{c}\text { Unit cell } \\
\text { parameter } \\
(\mathrm{nm})^{\mathrm{b}}\end{array}$ \\
\hline $\mathrm{CeO}_{2}$ & 13.8 & 5.400 \\
$0.1 \%$ & 14.2 & 5.403 \\
$0.5 \%$ & 14.2 & 5.400 \\
$2.0 \%$ & 14.2 & 5.402 \\
$5.0 \%$ & 14.2 & 5.402 \\
$10.0 \%$ & 13.8 & 5.395 \\
\hline
\end{tabular}

${ }^{a}$ Calculated from Scherrer equation based on (111) plane

${ }^{\mathrm{b}}$ Calculated from Bragg's law, and average value of (111), (200), (220), and (311) planes are provided

\section{Calculation of unit cell parameters}

The d-spacing values were calculated based on Bragg's law:

$$
n \lambda=2 d \sin \Theta
$$

( $n=$ diffraction order, $\lambda=$ wavelength of the incident $X$-rays, $d=d$-spacing value, $\Theta=$ angle of incidence)

As all samples showed an XRD peak of cubic fluorite structure of $\mathrm{CeO}_{2}$, The unit cell parameters were calculated based on the equation:

$$
\frac{1}{d^{2}}=\frac{h^{2}+k^{2}+l^{2}}{a^{2}}
$$

$(d=d$-spacing value, $a=$ unit cell parameter $, h, k, l=$ direction of planes in Miller indices)

The crystallite sizes of $\mathrm{CeO}_{2}$ of each sample showed similar values in the range of 13.8 to $14.2 \mathrm{~nm}$. Unit cell parameters also showed similar values in the range of 5.395 to $5.403 \mathrm{~nm}$. As the $\mathrm{CeO}_{2}$ support was calcined at the same condition $\left(500^{\circ} \mathrm{C}, 6 \mathrm{~h}\right)$, it showed a similar value even it is re-calcined after the impregnation of Pt. 
Table S2. The inlet and outlet gas composition

\begin{tabular}{|c|c|c|c|c|c|c|}
\hline \multicolumn{7}{|c|}{ Inlet gas composition (\%) (Dry basis) } \\
\hline Component & $\mathrm{CH}_{4}$ & $\mathrm{CO}_{2}$ & CO & $\mathbf{H}_{2}$ & $\mathbf{N}_{2}$ & SUM \\
\hline Conc. $(\%)$ & 2.35 & 21.50 & 39.70 & 27.05 & 9.40 & 100.00 \\
\hline \multicolumn{7}{|c|}{ Outlet gas composition (\%) (Dry basis) } \\
\hline $0.1 \% \mathrm{Pt} / \mathrm{CeO}_{2}$ & $\mathrm{CH}_{4}$ & $\mathrm{CO}_{2}$ & $\mathrm{CO}$ & $\mathbf{H}_{2}$ & $\mathbf{N}_{2}$ & SUM \\
\hline $4 \mathrm{~h}\left(\mathrm{H}_{2} \mathrm{~S} 0 \mathrm{ppm}\right)$ & 1.85 & 37.12 & 18.63 & 33.03 & 9.39 & 100.02 \\
\hline $10 \mathrm{~h}\left(\mathrm{H}_{2} \mathrm{~S} 500 \mathrm{ppm}\right)$ & 2.27 & 19.48 & 34.88 & 28.87 & 9.35 & 94.85 \\
\hline $16 \mathrm{~h}\left(\mathrm{H}_{2} \mathrm{~S}\right.$ off $)$ & 2.32 & 24.10 & 30.19 & 34.64 & 9.41 & 100.66 \\
\hline $0.5 \% \mathrm{Pt} / \mathrm{CeO}_{2}$ & $\mathrm{CH}_{4}$ & $\mathrm{CO}_{2}$ & $\mathrm{CO}$ & $\mathbf{H}_{2}$ & $\mathbf{N}_{2}$ & SUM \\
\hline $4 \mathrm{~h}\left(\mathrm{H}_{2} \mathrm{~S} 0 \mathrm{ppm}\right)$ & 1.73 & 42.99 & 7.92 & 39.44 & 9.42 & 101.50 \\
\hline $10 \mathrm{~h}\left(\mathrm{H}_{2} \mathrm{~S} 500 \mathrm{ppm}\right)$ & 2.27 & 20.11 & 29.80 & 33.45 & 9.33 & 94.96 \\
\hline $16 \mathrm{~h}\left(\mathrm{H}_{2} \mathrm{~S}\right.$ off $)$ & 2.30 & 24.77 & 19.29 & 44.42 & 9.36 & 100.14 \\
\hline $2.0 \% \mathrm{Pt} / \mathrm{CeO}_{2}$ & $\mathrm{CH}_{4}$ & $\mathrm{CO}_{2}$ & $\mathrm{CO}$ & $\mathbf{H}_{2}$ & $\mathbf{N}_{2}$ & SUM \\
\hline $4 \mathrm{~h}\left(\mathrm{H}_{2} \mathrm{~S} 0 \mathrm{ppm}\right)$ & 1.37 & 52.66 & 1.32 & 35.26 & 9.38 & 99.99 \\
\hline $10 \mathrm{~h}\left(\mathrm{H}_{2} \mathrm{~S} 500 \mathrm{ppm}\right)$ & 2.27 & 15.54 & 13.33 & 54.39 & 9.36 & 94.89 \\
\hline $16 \mathrm{~h}\left(\mathrm{H}_{2} \mathrm{~S}\right.$ off $)$ & 2.31 & 25.17 & 3.33 & 59.81 & 9.39 & 100.01 \\
\hline $5.0 \% \mathrm{Pt} / \mathrm{CeO}_{2}$ & $\mathrm{CH}_{4}$ & $\mathrm{CO}_{2}$ & $\mathrm{CO}$ & $\mathbf{H}_{2}$ & $\mathbf{N}_{2}$ & SUM \\
\hline $4 \mathrm{~h}\left(\mathrm{H}_{2} \mathrm{~S} 0 \mathrm{ppm}\right)$ & 1.42 & 45.23 & 2.57 & 41.90 & 9.34 & 100.46 \\
\hline $10 \mathrm{~h}\left(\mathrm{H}_{2} \mathrm{~S} 500 \mathrm{ppm}\right)$ & 2.26 & 20.30 & 28.23 & 34.85 & 9.31 & 94.95 \\
\hline $16 \mathrm{~h}\left(\mathrm{H}_{2} \mathrm{~S}\right.$ off $)$ & 2.31 & 24.46 & 20.37 & 43.69 & 9.40 & 100.23 \\
\hline $10.0 \% \mathrm{Pt} / \mathrm{CeO}_{2}$ & $\mathrm{CH}_{4}$ & $\mathrm{CO}_{2}$ & $\mathrm{CO}$ & $\mathbf{H}_{2}$ & $\mathbf{N}_{2}$ & SUM \\
\hline $4 \mathrm{~h}\left(\mathrm{H}_{2} \mathrm{~S} 0 \mathrm{ppm}\right)$ & 1.44 & 50.55 & 6.61 & 32.49 & 9.43 & 100.52 \\
\hline $10 \mathrm{~h}\left(\mathrm{H}_{2} \mathrm{~S} 500 \mathrm{ppm}\right)$ & 2.28 & 19.94 & 30.30 & 33.20 & 9.36 & 95.08 \\
\hline $16 \mathrm{~h}\left(\mathrm{H}_{2} \mathrm{~S}\right.$ off $)$ & 2.32 & 24.49 & 17.79 & 46.33 & 9.41 & 100.34 \\
\hline
\end{tabular}

The value of SUM of the " $10 \mathrm{~h}\left(\mathrm{H}_{2} \mathrm{~S} 500 \mathrm{ppm}\right)$ " is around 95, because of the injection of $\mathrm{H}_{2} \mathrm{~S} / \mathrm{Ar}$ gas. Ar is used as carrier gas on a thermal conductivity detector of the Micro-GC for the analysis of $\mathrm{H}_{2}$ typically, so the Micro-GC cannot detect Ar. Ar was chosen as the diluent gas in $\mathrm{H}_{2} \mathrm{~S} / \mathrm{Ar}$ because $\mathrm{N}_{2}$ is a standard for calculating the $\mathrm{CO}$ conversion. Additional injection of $\mathrm{N}_{2}$ will directly affect the standard, which makes an error in the calculation of the $\mathrm{CO}$ conversion. 